УДК 616.24.012.1-008.518

DOI 10.11603/bmbr.2706-6290.2020.4.11810

М. М. Регеда-Фурдичко, М. С. Регеда, С. М. Регеда, Л. О. Фурдичко

Львівський національний медичний університет імені Данила Галицького

Львівський медичний інститут

\title{
ВПЛИВ ТІОТРИАЗОЛІНУ НА ПЕРВИННУ І ВТОРИННУ ІМУННУ ВІДПОВІДЬ ЗА УМОВ ФОРМУВАННЯ КОНТАКТНОГО ДЕРМАТИТУ ТА ПНЕВМОНІЇ
}

\section{Вплив тіотриазоліну на первинну і вторинну імунну відповідь за умов фрормування контактного дерматиту та пневмонії}

М. М. Регеда-Фурдичко, М. С. Регеда, С. М. Регеда, Л. О. Фурдичко

Львівський національний медичний університет імені Данила Галицького

Львівський медичний інститут

Резюме. Контактний дерматит (КД) і пневмонія залишаються найбільш розповсюдженими захворюваннями серед патології бронхолегеневого апарату $i$ шкіри.

Мета дослідження - 3'ясувати рівень активності імуноглобулінів A, M, G у крові та встановити коригувальний вплив на них тіотриазоліну в умовах КД і експериментальної пневмонії (ЕП).

Матеріали і методи. Були проведені дослідження на 55 морських свинках-самцях масою 180-210 2. Контактний дерматит відтворювали за методом В. А. Волкової, ЕП - за методом В. Н. Шляпникова, T. л. Солодова. Вміст імуноглобулінів A, M, G в крові визначали за методом Е. Ф. Чернушенко, Л. С. Когосова. Тіотриазолін вводили щоденно у дозі 100 мг на 1 кг маси упродовж 10 діб (з 8-ї до 18-ї доби) ЕП і КД. Тварин декапітували під ефрірним наркозом на 4-ту, 8-му, 10-ту і 18-ту доби до та після застосування цього препарату.

Результати. Встановлено, що КД і ЕП (4-ma, 8-ма, 10-та і 18-та доби) супроводжується підвищенням вмісту IgA в крові відповідно на 46,4 \% ( $<<0,05)$, $84,6 \%(p<0,05), 115,4 \%(p<0,001)$ i $123,1 \%(p<0,001)$. $\operatorname{lgM~відповідно~на~50,0~\% ~(~} p<0,05), 58,3 \%(p<0,05)$, $91,7 \%(p<0,05)$ i 103,3\% (p<0,001), IgG - на 49,0\% $(p<0,05), 73,6 \%(p<0,05), 86,8 \%(p<0,05)$ i $90,6 \%$ $(p<0,05)$ проти контролю до лікування. Застосування тіотриазоліну приводило до зниження IgA, IgM i IgG в крові відповідно на 27,5\% (p<0,05), 36,0\% $(p<0,05) i$ 29,7 \% $(p<0,05)$ відносно групи тварин з ЕП і КД до лікування, що свідчить про його імунокоригувальний ефект.

Висновки. Контактний дерматит і експериментальна пневмонія супроводжуються поступовим зростанням рівня IgA, M, G в крові упродовж усього періоду їх розвитку з домінуванням у найпізніший термін спостереження (10-та і 18-та доби), що дає підстави констатувати про їх активну участь у механізмах фрормування первинної та вторинної імунної відповіді. Застосування
The influence of thiotriazoline on the primary and secondary immune response in the formation of contact dermatitis and pneumonia

M. M. Regeda-Furdychko, M. S. Regeda, S. M. Regeda, L. O. Furdychko

Danylo Halytsky Lviv National Medical University Lviv Medical Institute

e-mail: Ivivmedinst@gmail.com

Summary. Contact dermatitis $(C D)$ and pneumonia remain the most common diseases among the pathology of the bronchopulmonary system and skin.

The aim of the study - to determine the level of activity of immunoglobulins A, M, G in the blood and to establish the corrective effect of thiotriazoline on them in the conditions of $C D$ and experimental pneumonia (EP).

Materials and Methods. Studies were performed on 55 guinea pigs, males, weighing 180-210 g. Contact dermatitis was reproduced by the method of V. A. Volkova, EP was reproduced by the method of V. N. Shlyapnikov, $T$. L. Solodova. The content of immunoglobulins A, M, G in the blood was determined by the method of E. F. Chernushenko, L. S. Kogosova. Thiotriazoline was administered daily at a dose of $100 \mathrm{mg}$ per $1 \mathrm{~kg}$ of body weight for 10 days (from the $8^{\text {th }}$ to the $18^{\text {th }}$ day) EP and CD. Animals were decapitated under ether anesthesia on the $4^{\text {th }}, 8^{\text {th }}, 10^{\text {th }}$ and $18^{\text {th }}$ days before and after administration of this drug.

Results. It was found that $C D$ and EP $\left(4^{\text {th }}, 8^{\text {th }}, 10^{\text {th }}\right.$ and $18^{\text {th }}$ days) is accompanied by an increase in Ig A content in the blood by $46.4 \%$ ( $p<0.05), 84.6 \%$ ( $p<0.05), 115.4 \%$ ( $p$ $<0.001)$ and $123.1 \%(p<0.001) . \lg M$ by $50.0 \%(p<0.05)$, $58.3 \%(p<0.05), 91.7 \%(p<0.05)$ and $103.3 \%(p<0.001)$, respectively; Ig $G$ by $49.0 \%(p<0.05), 73.6 \%(p<0.05)$, $86.8 \%(p<0.05)$ and $90.6 \%(p<0.05)$ against control before treatment. The use of thiotriazoline led to a decrease in $\lg \mathrm{A}, \lg \mathrm{M}$ and $\lg \mathrm{G}$ in the blood by $27.5 \%(p<0.05), 36.0 \%$ $(p<0.05)$ and $29.7 \%(p<0,05)$ in relation to a group of animals with EP and CD before treatment, which indicates its immunocorrective effect.

Conclusions. Contact dermatitis and experimental pneumonia are accompanied by a gradual increase in the level of $\lg A, M, G$ in the blood throughout the period of their development with dominance in the latest period of observation (10 th and $18^{\text {th }}$ days), which gives grounds to state their active participation in the mechanisms of formation primary and secondary immune response. The 
тіотриазоліну зумовлювало імунокоригувальну дію на рівень імуноглобулінів у крові при КД і ЕП.

Ключові слова: контактний дерматит; пневмонія; тіотриазолін; імуноглобуліни.

\section{ВСТУП}

Контактний дерматит (КД) як і пневмонія залишаються важливими медико-соціальними проблемами, оскільки є найпоширенішими патологіями у пульмонології і дерматології, зумовлюють різноманітні ускладнення та спричиняють періоди тимчасової непрацездатності, рідше інвалідність, інколи смерть. За останні десятиріччя поєднана патологія супроводжується тяжким перебігом, складнощами в лікуванні, а також наявністю одного або кількох супутніх захворювань, здатні помітно впливати і змінювати фрізіологічні процеси в організмі, знижувати його адаптаційні можливості $[4,7,8]$. Тому коі поліморбідності в терапії на сьогодні приділяють велику увагу не лише експериментатори, але й клініцисти. Не вивченим до кінця нині є питання, що стосуються механізмів імунної відповіді не тільки при одній патології, а тим більше в умовах поєднаних захворювань, зокрема при КД і пневмонії. У доступній нам літературі практично відсутні такого роду дослідження.

Метою дослідження було з'ясувати рівень активностіімуноглобулінів A, M, Gукровітавстановити коригувальний вплив на них тіотриазоліну в умовах контактного дерматиту й експериментальної пневмонії.

\section{МАТЕРІАЛИ I МЕТОДИ}

Експериментальне дослідження проводили на 55 морських свинках-самцях масою 180-210 г, яких поділили на шість груп. Перша - контроль (інтактні тварини, 10). Друга, третя, четверта і п'ята групи - морські свинки з експериментальною пневмонією (ЕП) і контактним дерматитом (КД) відповідно на 4-ту, 8-му, 10-ту і 18-ту доби експерименту (по 9 тварин у кожній групі) до лікування і шоста група тварин (по 9 тварин у кожній групі) - ЕП і КД на 18-ту добу їх розвитку після корекції препаратом «Тіотриазолін», який вводили на 100 мг на кг маси тіла внутрішньом'язово щоденно упродовж 10 діб з 8-ї до 18-ї доби експерименту, оскільки в цей період патологічного процесу були виявлені найбільш виражені зміни імунних показників. Ми вибрали фріксовані доби (4-та, 8-ма, 10-та і 18-та) для досліджень, які відповідали класичним стадіям запального процесу. ЕП викликали за методом В. Н. Шляпникова, Т. Л. Солодова [2]. КД відтворювали на тваринах за методом В. А. Волковой [1]. Рівень імуноглобулінів $A, M, G$ в крові визначали за методом Е. Ф. Чернушенко, Л. С. Когосова [7]. use of thiotriazoline caused an immunocorrective effect on the level of immunoglobulins in the blood in $C D$ and EP.

Key words: contact dermatitis; pneumonia; thiotriazoline; immunoglobulins.

Статистичне опрацювання одержаних цифрових результатів здійснювали за методом Стьюдента.

\section{РЕЗУЛЬТАТИ Й ОБГОВОРЕННЯ}

Відомо 3 літератури, що IgA перебуває у біологічних рідинах (слина, жовч, сеча, бронхіальний і шлунково-кишковий тракт) і відіграє важливу роль у розвитку механізмів місцевого імунітету, протидіє масованому надходженню антигенів крізь слизові оболонки, перешкоджає прикріпленню бактерій до слизових, нейтралізує ентеротоксини, сприяє фрагоцитозу $[3,5,6]$. Тому його вивчення у крові при КД і ЕП має таке важливе значення. Ми встановили, що в динаміці (4-та, 8-ма, 10-та і 18-та доби) формування цих поєднаних патологічних процесів відбувається суттєве поступове зростання вмісту IgA відповідно на 46,4\% $(p<0,05)$, $84,6 \%(p<0,05), \quad 115,4 \%(p<0,001)$ i $123,1 \%$ $(p<0,001)$ відносно інтактної групи тварин, що свідчить про інтенсивне антигенне навантаження на організм і адекватну його імунну відповідь.

Не менш важливим для організму людей і тварин відіграє IgM, на долю якого припадає $10 \%$ загальної кількості імуноглобулінів. Імуноглобуліни цього класу синтезуються у відповідь на більшість антигенів на ранніх стадіях імунних реакцій, тому IgМ належать до первинної імунної відповіді, а також вони ефективніше за інші антитіла активують систему комплементу $[3,5,6]$.

Результати досліджень показали, що в процесі срормування КД і ЕД (4-та, 8-ма, 10-та і 18-та доби) спостерігається поступове підвищення рівня IgM відповідно на 50,0 \% ( $p<0,05), 58,3 \%(p<0,05), 91,7$ $\%(p<0,05)$ і 103,3 \% (p<0,001) проти контролю, що може вказувати на первинну імунну відповідь і активацію комплементарної активності.

Літературні джерела свідчать про те, що вміст IgG складає 70-75 \% загальної кількості імуноглобулінів, добре активують комплемент і є імуноглобуліном вторинної імунної відповіді. 3 цим IgG пов'язують захист від грампозитивних бактерій, вірусів, токсинів $[3,5,6]$.

Результати імунологічних дослідження показали, що вміст IgG в крові зростає поступово (4-та, 8-ма, 10-та доби) відповідно на 49,0 \% ( $<<0,05)$, $73,6 \%(p<0,05), 86,8 \%(p<0,05)$ і досягає свого апогею на 18-ту добу експерименту, підвищується на 90,6 \% $(p<0,05)$, порівняно з першою групою тварин, що вказує на його активну участь у вторинній імунній відповіді за умов формування КД та ЕП до лікування. 
Застосування тіотриазоліну спричинило зниження вмісту IgA, M, G в крові відповідно на $27,5 \%(p<0,05), 36,0 \%(p<0,05), 29,7 \%$ $(p<0,05)$ відносно групи тварин з ЕП і КД, які не піддавалися впливу цього препарату, що свідчить про його імунокоригувальний вплив за умов розвитку цих експериментальних моделей хвороб (рис.).

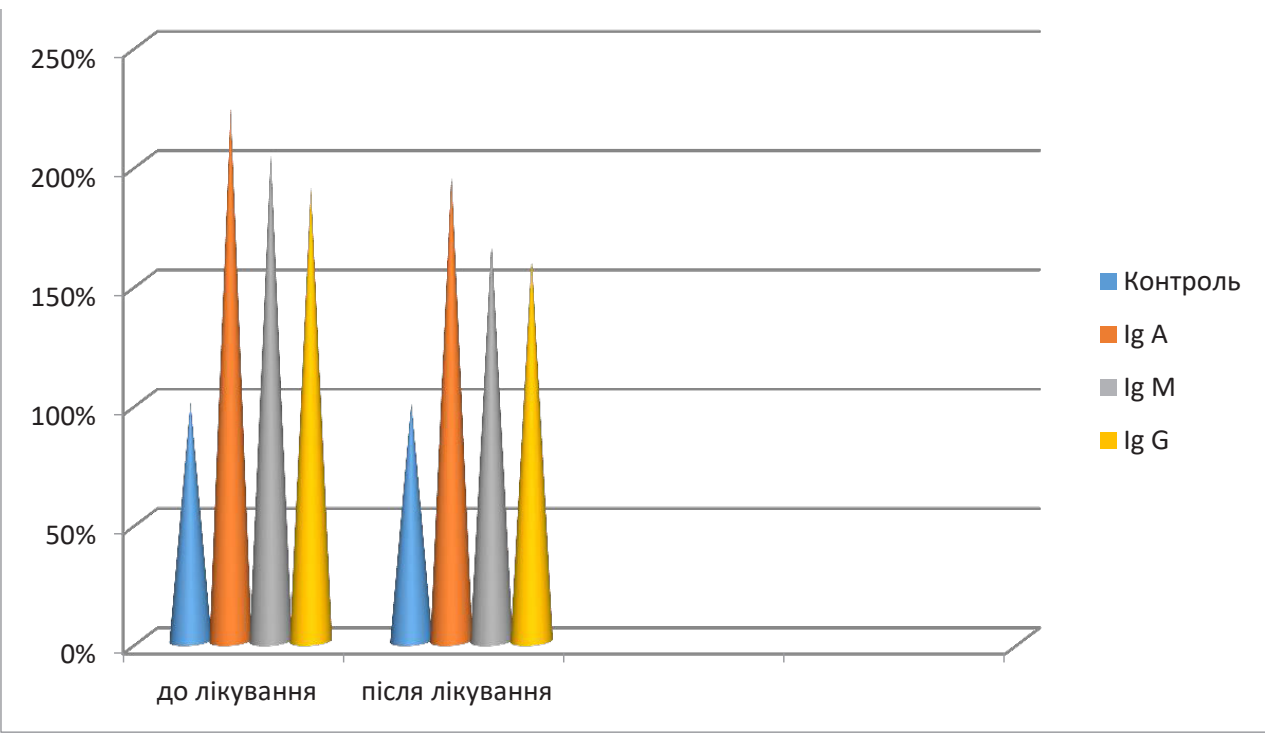

Рис. Вплив тіотриазоліну на вміст імуноглобулінів A, M, G в крові при контактному дерматиті й експериментальній пневмонії (\% порівняння до і після лікування на 18-ту добу експерименту).

\section{ВИСНОВкИ}

Контактний дерматит і експериментальна пневмонія супроводжуються поступовим зростанням рівня $\lg \mathrm{A}, \mathrm{M}, \mathrm{G}$ в крові впродовж усього періоду їх розвитку з домінуванням у найпізніший термін спостереження

\section{СПИСОК ЛІТЕРАТУРИ}

1. Волкова В. А. Вивчення лікувальної ефективності нової мазі з ліпофільним комплексом із кори осики «Тремулін» за умов неалергічного контактного дерматиту в щурів / В. А. Волкова, І. В. Кучинська, Т. І. Тюпка // Фармакологія та лікарська токсикологія. - 2010. - С.7-12.

2. Экспериментальные модели острых пневмоний, вызванных условно-патологическими бактериями и их ассоциацией : метод. указания / сост. : В. Н. Шляпников, Т. л. Солодова [и др.]. - Саратов, 1998. - 30 с.

3. Казмірчук В. Є. Клінічна імунологія і алергологія / В. Є. Казмірчук, Л. В. Ковальчук. - Вінниця : Нова книга, 2006. - C. 528.

4. Регеда М. С. Вплив препарату «Тіотриазолін» на зрушення імунної системи в крові морських свинок за умов формування експериментальної бронхіальної астми / М. С. Регеда, М. А. Колішецька, В. Р. Юревич // (10-та і 18-та доби), що дає підстави констатувати про їх активну участь у механізмах формування первинної та вторинної імунної відповіді. Застосування тіотриазоліну зумовлювало імунокоригувальну дію на рівень імуноглобулінів у крові при КД і ЕП.

Медична та клінічна хімія. - 2015. - Т. 17, № 2 (63). C. $52-55$.

5. Ройт А. Иммунология / А. Ройт, Дж. Бростофрф. М. : Мир, 2000. - С. 582.

6. Сапиашвили Р. И. Основы фризиологии иммунной системы / Р. И. Сапиашвили. - М. : Медицина, 2003. C. 239 .

7. Чернушенко Е. Ф. Иммунология и иммунопатология заболеваний легких / Е. Ф. Чернушенко, Л. С. Когосова. - К. : Здоров'я, 1981. - 208 с.

8. Ференц Н. М. Роль процесів перекисного окиснення ліпідів і системи антиоксидантного захисту в печінці у патогенезі експериментальної пневмонії та іммобілізаційного стресу і корекція їх порушень корвітином / Н. М. Ференц, В. Р. Юревич // Медична хімія. - 2015. T. 17, № 4(62). - C. 10-103. 


\section{REFERENCES}

1. Volkova VA, Kuchynska IV, Tyupka TI. Study of the therapeutic efficacy of a new ointment with a lipophilic complex from aspen bark "Tremulin" under conditions of nonallergic contact dermatitis in rats. Farm ta lik toksykol. 2010; 7-12. Ukrainian.

2. Shlyapnikov VN, Solodova TL. Experimental models of acute pneumonia caused by opportunistic bacteria and their association: a method. instructions. [Экспериментальные модели острых пневмоний, вызванных условно-патологическими бактериями и их ассоциацией: метод. указания] Saratov; 1998. Russian.

3. Kazmirchuk VE, Kovalchuk LV. Clinical immunology and allergology. [Клінічна імунологія і алергологія] Vinnytsia: Nova knyha; 2006. Ukrainian.

4. Regeda MS, Kolishetskaya MA, Yurevich VR. [Influence of the drug "thiotriazoline" on the shift of the immune system in the blood of guinea pigs under the conditions of the formation of experimental bronchial asthma]. Med i klin khim. 2015;17 2 (63): 52-5. Ukrainian.

5. Royt A, Brostoff J. Immunology. [Иммунология] Moscow: Mir; 2000. Russian.

6. Sapiashvili RI. Fundamentals of the physiology of the immune system. [Основы фризиологии иммунной системы] Moscow: Meditsina; 2003. Russian.

7. Chernushenko EF, Kogosova LS. Immunology and immunopathology of lung diseases. [Иммунология и иммунопатология заболеваний легких] Kyiv: Zdorovia; 1981. Russian.

8. Ferents NM, Yurevich VR. [The role of lipid peroxidation processes and antioxidant defense system in the liver in the pathogenesis of experimental pneumonia and immobilization stress and correction of their disorders by corvitin]. Med khim. 2015;17 4 (62): 10-103. Ukrainian. 